Article

\title{
The Impact of International Trade on Sustainable Development in Saudi Arabia
}

\author{
Mounir Belloumi * (D) and Atef Alshehry \\ College of Administrative Sciences, Najran University, Najran 1988, Saudi Arabia; asalshehry@nu.edu.sa \\ * Correspondence: mounir.balloumi@gmail.com
}

Received: 17 June 2020; Accepted: 2 July 2020; Published: 5 July 2020

\begin{abstract}
This study examines the impact trade openness has on sustainable development in Saudi Arabia. It does so by employing the autoregressive distributed lag cointegration framework, using annual data over the period 1971 to 2016. Overall, the findings suggest the existence of a long-term relationship between trade openness and two indicators of sustainable development-are economic growth and environmental quality. Results indicate that trade openness does not affect both indicators of economic growth and environmental quality in the short-term. However, in the long-term, trade openness has a significant negative impact on economic growth when it is proxied by the variables the ratio of exports plus imports to GDP, and the ratio of exports to GDP; but a significant positive impact for the variable the ratio of imports to GDP. In addition, trade openness negatively affects environmental quality in the long-term. The tests used for diagnosing models show that they are valid, and thus, our findings are robust. Comprehensively, we find that trade openness could have led to the degradation of sustainable development in Saudi Arabia for the past fourteen years.
\end{abstract}

Keywords: trade openness; economic growth; environmental quality; sustainable development; Saudi Arabia

\section{Introduction}

According to international organizations, especially the World Bank and the World Trade Organization (WTO), there is a strong association between international trade and sustainable development. These organizations have emphasized many programs on trade and sustainable development, which aim to propose the adequate trade strategies that could lead to boost economic growth and protect the environment for future generations (e.g., [1-3]). The United Nations Conference on Trade and Development [4] advanced that international trade could be a potential driver for economic development. Economic development goals have become an important mission, targeting many countries around the world, including Saudi Arabia. The relationship between trade openness and sustainable development is one of the most important questions in the economic literature, faced with renewed interest in recent years.

More than eight years after the political and social changes in 2011 in the majority of Arab countries, their economic situations are always oscillating between challenges and potential to be valued. Even if the current economic and financial situations are characterized by a vulnerability for certain Middle East and North Africa (MENA) countries, they present positive signals allowing them to be on the path of growth. Since the mercantilists, international trade has been seen as a source of wealth. It is of great consequence for countries as a driver for technological spillovers. International trade can lead to promote innovation, form capital, improve productivity, and make the allocation of resources more efficient in importing countries. For the neoclassical economic theory, trade openness can encourage capital formation and improve the efficiency of resource allocation, thereby facilitating the 
improvement of the quality of economic growth [5]. The endogenous growth theory suggests that openness to international trade is mainly improving the quality of economic growth by accelerating innovation and stimulating factor productivity [6-8]. Empirically, the dynamic relationship between trade openness and economic growth has been analyzed by many previous studies, but without clear conclusions. However, the impact of international trade on the environment is ambiguous theoretically and empirically. It depends on the scale effect, the composition effect and the technique effect $[9,10]$.

Despite the lack of agreement regarding the impact of international trade on economic growth and environmental degradation, the researches that have investigated the impact of international trade on sustainable development in Saudi Arabia are very rare. Besides, the literature suggests many reasons for the inconclusive results on the trade-growth nexus and the trade-environment nexus. Among these reasons, there are the different proxies used for trade openness, the various periods, and the different methodologies used. In addition, trade liberalization is accompanied by other policy measures that cannot be captured by methodologies using longitudinal data [11,12]. To that effect, this research analyzes the impacts of trade openness on both indicators of sustainable development in Saudi Arabia using the autoregressive distributed lag (ARDL) cointegration framework by employing annual data over the period 1971 to 2016 . We consider both pillars of sustainable development that are economic growth and environmental quality. The real GDP per capita is the proxy of economic growth, whereas the proxy of environmental quality is carbon dioxide $\left(\mathrm{CO}_{2}\right)$ emissions per capita. We investigate the effect of trade openness on both indicators of sustainable development by integrating the control variables of domestic investment, energy consumption, foreign direct investment, and finance development. Thus, our research questions are twofold. Does trade openness enhance economic growth in Saudi Arabia? In addition, does trade openness lead to an increase in $\mathrm{CO}_{2}$ emissions in Saudi Arabia?

The originality of this study is that it is the first one to investigate the impact of trade openness on economic growth and $\mathrm{CO}_{2}$ emissions simultaneously for the case of Saudi Arabia. It is among the few studies that include trade openness, FDI, energy use, and finance development together to explain both main pillars of sustainable development. Furthermore, this study employs a long time series of yearly data for the available period (1971-2016). In addition, even Saudi Arabia became a member of WTO on 11 December 2005, and it has not worked to develop a scheme to examine the effects of trade openness on the country's sustainable development. Besides, what has driven this research is that Saudi Arabia becomes among the first worldwide $\mathrm{CO}_{2}$ per capita emitter countries. For example, $\mathrm{CO}_{2}$ emissions attained 19.52 metric tons per capita in 2014 for Saudi Arabia, whereas they were 16.49 metric tons per capita for the United States. In addition, since the 1970th, the Saudi Arabian share of international trade in GDP has exceeded 70\% (WDI, 2019).

The remainder of the paper is arranged as follows. Section 2 is devoted to a brief review of previous empirical studies analyzing the impact of trade openness on economic growth and environmental quality. In Section 3, we present the various ARDL models estimated and the data used in the study. In Section 4, we discuss and interpret our results. Finally, Section 5 closes the paper by providing some conclusions and policy implications.

\section{Literature Review}

International trade can play an important role in enhancing economic growth through the specialization of each country in producing the products in which it has a comparative advantage and by transferring the resources among the different countries. However, international trade can be detrimental to the environment. Theoretically, international trade has an uncertain and debatable impact on the environment. It can affect the environment through three different main channels that are the scale effect, the composition effect and the technique effect. The scale effect states that increased international trade can lead to an increase in production, and all other things being equal, greenhouse gas emissions increase. The composition effect corresponds to the change in the sectoral 
composition of a country, due to its specialization in producing the products or services in which it has a comparative advantage. It can be beneficial or not to the environment, depending on the country. The technique effect of international trade positively affects the environment by cleaner techniques of production $[9,10]$.

There is a substantial literature review on the links between international trade and the two indicators of sustainable development. Previous studies are undertaken for many countries and regions by using various variables and methodologies for different span periods. Their findings would provide a better understanding of the potential role of international trade in economic growth and environmental degradation.

The advances in the endogenous growth theory inspire the literature on the question of whether international trade contributes to economic growth. Many interesting previous studies have investigated the international trade-economic growth-nexus [6,13-15]. In this work, we consider some previous studies that consider the global scale; then, studies that consider some emerging countries, including the Kingdom of Saudi Arabia; and finally, studies that look at MENA and Gulf Cooperation Council (GCC) countries specifically. Among those, Frankel and Romer [16] show that international trade has a positive impact on income for the case of 63 countries. Ghirmay et al. [17] investigated the impact of exports on economic growth in 19 developing countries using a vector error correction model (VECM). They obtain a long-term relationship between trade openness and economic growth in twelve of the developing countries investigated. They note that East Asia and Southeast Asia have not the same growth process. In the same line, Mamun and Nath [18] analyze the relationship between exports and economic growth in Bangladesh. They report the presence of a long-term unidirectional causality running from exports to Bangladesh economic growth. Not later, Felbermayr [19] analyzes the link between income per capita and the trade openness using a dynamic panel data model. He finds that trade openness positively affects income for the various countries investigated. However, Reppas and Christopoulos [20] find only a unidirectional causality running from economic growth to exports for a panel of Asian and African countries. Hsiao and Hsiao [21] report the existence of bidirectional causality between exports and GDP when investigating the exports-GDP-nexus for the case of Asian countries over the period 1986-2004. In this vein, Narayan et al. [22] investigate the relationship between exports and economic growth for Fiji and Papua New Guinea. Their findings confirm the export-led growth hypothesis (ELGH) in the long-term for Fiji, while the ELGH is confirmed in the short-term for Papua New Guinea.

Rahman [23] analyzes the impact of exports on real GDP for some Asian countries (Bangladesh, India, Pakistan and Sri Lanka) using the ARDL cointegration approach over the period 1976-2006. He reports that exports could affect positively the economic output in Bangladesh and India in the short-term. Jenkins and Katircioglu [24] find the presence of a cointegrating relationship between international trade, financial development and economic growth for Cyprus, but the unidirectional causality is running from economic growth to international trade and not the reverse. By investigating the causal relationships between the ratio of exports plus imports to GDP and GDP per capita for a group of countries over the period 1970-2009, Gries and Redlin [25] find a positive bidirectional causality between both variables in the long-term, but trade openness negatively affects economic growth in the short-term. Moreover, they show that the effect of trade openness on economic growth depends on a country's stage of development. Muhammad et al. [26] find a long-term unidirectional causality running from trade openness to economic growth for five South Asian countries. Similarly, Fetahi-Vehapi et al. [27] show that the positive effect of trade openness on economic growth in 10 South-East European countries depends on the initial level of income per capita. Moreover, trade openness enhances economic growth for countries with high levels of income and high levels of foreign and domestic investments. However, Musila and Yiheyis [28] find no significant impact of trade openness on economic growth for Kenya. In the same line, the Gokmenoglu et al. [29]'s study does not reveal causality running from international trade to economic growth for the case of Pakistan. Many studies have investigated the trade-growth nexus in emerging countries. Baharumshah and 
Rashid [30] find a cointegrating association between the variables of exports, imports and GDP for the case of Malaysia. Besides, their results report that imports are among the main drivers of economic growth in Malaysia. By studying the relationship between trade openness, energy consumption, financial development and economic growth for China, Shahbaz et al. [31] report a positive bidirectional causality linking trade openness to economic growth. For the case of Saudi Arabia, Alhowaish [32] finds that exports have a positive impact on economic output in both the short- and long-term, whereas imports do not affect its economic growth. By employing the same methodology and the same variables used by Altaee et al. [33], Rehman et al. [34] find that there is a unidirectional causality running from trade openness to economic growth in Saudi Arabia. In the same line, Kumar et al. [35] study the trade openness-economic growth-nexus for South Africa. They note the presence of a positive bidirectional causal relationship linking trade openness to economic growth. Cetin [36] studies the dynamic causal relationships between trade openness and economic growth for Turkey over the period 1980-2014 by employing the ARDL cointegration and Johansen multivariate cointegration techniques. His findings reveal the presence of a long-term unidirectional causality running from trade openness to economic growth. Sunde [37] analyses the impact of exports on economic growth in South Africa using the ARDL bounds cointegration approach over the period 1990-2014. His results validate the export-led growth hypothesis for the case of South Africa. Ridzuan et al. [38] show that trade openness leads to higher economic growth for Singapore. As Sunde [37], the results of Fayyaz et al. [39] indicate that export-led growth hypothesis is validated in both the short- and long-term for the case of ASEAN5 countries (Indonesia, Malaysia, Philippines, Thailand and Vietnam). Kong et al. [40] investigate the relationship between the degree of trade openness and economic growth by including a variable representing the exchange rate fluctuations in China. They report that the degree openness may have a positive impact on economic growth in both the short- and long-term. Few studies have analyzed the impact of international trade on economic growth for MENA countries, particularly GCC ones. When analyzing the relationship between economic growth and international trade for Jordan over the period 1990-2008, Alalaya [41] shows a unidirectional causality running from international trade to economic growth. Marc [42] studies seven MENA countries (Algeria, Egypt, Jordan, Morocco, Syria, Tunisia and Turkey) over the period 1982-2009. His results indicate that exports create positive spillovers effects on economic growth in the group of countries studied. Jouini [43] analyses the dynamic relationship between trade openness and economic growth in the six GCC countries using the Pooled Mean Group estimation method. His results indicate that the variables are cointegrated, and trade openness has a positive effect on economic growth in both the short- and long-term. By using the Johansen cointegration approach, Granger causality tests and the variance decomposition analysis, Altaee et al. [33] find that the variables of trade openness, finance development and economic growth are cointegrated in Oman. Their findings also show that trade openness boosts Oman's economic growth. According to Omri et al. [44], there is bidirectional causality between trade openness and economic growth in 12 MENA countries.

Overall, the findings are mixed. Researchers have not yet agreed whether trade openness can have a significant positive impact on economic growth. This may be due in part to several reasons such as different periods used, various proxies for trade openness, various techniques employed in the previous studies, etc. Most of the studies using cross-sectional have found a positive relationship between trade openness and economic growth [45].

Even many previous empirical studies have contributed to the debate over international trade-environmental quality-nexus; there is no consensus about this relationship. Various studies have reported the positive impact of trade openness on the environment (e.g., [9,46-49]), whereas others have found that trade is bad for the environment (e.g., [50-52]). As examples of the positive effects of international trade, Frankel and Rose [47] show that trade could lead to reducing $\mathrm{SO}_{2}$ and $\mathrm{NO}_{2}$ emissions. In the same line, Dean and Lovely [48] find that trade openness leads to a decreases in air and water pollutions for the case of China. More recently, Le et al. [49] find also that more openness to international trade may decrease $\mathrm{CO}_{2}$ emissions in China, and thus, leads to enhance its environmental quality. 
Cole [51] studies the trade flows of pollution-intensive products between North and South trade. His findings indicate that less developed countries do not adopt rigorous environmental regulations in order to attract more foreign investments in less pollution-intensive industries. This is well known by what is so-called the "pollution haven hypothesis" (PHH). In the same vein, Managi et al. [52] showed that a high degree of openness could result in increasing the levels of $\mathrm{SO}_{2}$ and $\mathrm{CO}_{2}$ emissions in non-OECD countries. Le et al. [53] investigate the international trade-environment-nexus for 98 countries. Overall, their results show that trade openness leads to environmental deterioration. Halicioglu and Ketenci [54] study the effects of international trade on environmental quality for some transition countries by employing the ARDL and Generalized Method of Moments (GMM) techniques. The results of both techniques confirm the displacement hypothesis for Armenia, Estonia, Latvia, Kyrgyzstan and Russia. By employing a panel data for 105 countries classified into three groups (low, middle and high-income countries), Shahbaz et al. [55] find that trade openness deteriorates environment for all the groups.

For the case of some emerging countries, Ertugrul et al. [56] find that trade openness increases $\mathrm{CO}_{2}$ emissions in China, India, Indonesia, and Turkey, whereas it does not affect the environment in Brazil, Korea, and Thailand. Shahzad et al. [57] examine the relationship between trade openness and $\mathrm{CO}_{2}$ emissions for Pakistan by employing the ARDL cointegration approach over the period of 1971 to 2011 . Their results indicate that a $1 \%$ increase in the degree of openness will lead to an increase in $\mathrm{CO}_{2}$ emissions by $0.122 \%$ and $0.247 \%$ in the short- and long-term, respectively. Moreover, they report that trade openness causes a unidirectional impact on $\mathrm{CO}_{2}$ emissions. Lin [58] finds that for China, trade openness could lead to the deterioration of environmental quality measured by $\mathrm{SO}_{2}, \mathrm{NO}_{2}$, and Aerosol concentration. Lastly, Sheikh et al. [59] study the link between openness to international trade and sustainable development in India using the ARDL model. Their findings indicate the presence of a negative relationship between trade openness and a composite indicator of sustainable development. Among MENA countries, Ozturk and Acaravci [60] show that more openness to international trade increases the levels of $\mathrm{CO}_{2}$ emissions in Turkey. Moreover, Omri et al. [44] find that there is a unidirectional causality running from trade openness to $\mathrm{CO}_{2}$ emissions in $12 \mathrm{MENA}$ countries.

\section{Data and Methods}

This study uses annual data starting from 1971 to 2016 for Saudi Arabia by employing the ARDL cointegration approach. This approach is initiated in three steps. Firstly, we check the stationarity of all the variables under investigation by employing some conventional unit root tests, such as the augmented Dickey-Fuller (ADF) test [61], the Phillips-Perron (PP) test [62], and the DF-GLS test developed by Elliott, Rothenberg and Stock [63]. Secondly, when all the variables are integrated of order zero or one, we check the cointegration relationships using the bounds test of Pesaran et al. [64]. Thirdly, in the case of presence of cointegrating association, we estimate the short- and long-term coefficients from the error correction models.

\subsection{Data}

The data used in this study concerned domestic investment, foreign direct investment, energy consumption per capita (EUC), trade openness (TO), finance development (FD), real GDP per capita (GDPC) and $\mathrm{CO}_{2}$ emissions per capita (CO2C) - which all are obtained from the World Development Indicators (WDI, 2018) published online by the World Bank. The share of gross fixed capital formation in GDP (GFCF) assigns the variable of domestic investment. The variable of economic growth is approached by the value of per capita GDP at constant prices. The variable per capita $\mathrm{CO}_{2}$ emissions is used as an indicator of environmental quality. The variable trade openness is expressed by either the ratio of exports plus imports to GDP, the ratio of exports to GDP (EX), or the ratio of imports to GDP (IMP). FDI inflows are measured as a share of GDP (FDI). Finance development is proxied by the ratio of credit accorded to private sector (FD). Except FDI, all the variables are transformed into their natural logarithms for the purpose of statistical analysis. 
Table 1 reports the descriptive statistics of the different variables at their levels. We observe that the share of exports in GDP is more important than that of imports in GDP in Saudi Arabia. The mean and median values of exports to GDP are both about $47 \%$, whereas they are about $30 \%$ for imports to GDP. Furthermore, the share of exports plus imports in GDP is important in Saudi Arabia. Their mean and median values are equal, respectively, to $77.62 \%$ and $75.61 \%$. The share of exports plus imports attained $120 \%$ in 1973. Recently, the values of trade openness are about $60 \%(60.85 \%$ in 2016 and $61.9 \%$ in 2017). This decrease in the degree of openness of Saudi Arabia is explained by the decrease in the value of oil exports. The worldwide average of trade openness for 2017 was $91.59 \%$. According to the degree of openness, Saudi Arabia is ranked 103 in 2017 (TheGlobalEconomy.com, The World Bank). Besides that, Saudi exports are mainly based on oil exports. The mean of the share of oil exports in merchandise exports for the period 1971-2016 is about 90\% in Saudi Arabia (WDI, 2018). As shown by the standard deviation values, the share of exports to GDP variable is more volatile than that of exports plus imports to GDP and the share of imports to GDP. The matrix of correlation is presented in Table 2. The coefficients of correlation between the different variables are reported with their levels of significance. It is shown that real GDP per capita is correlated to all other variables except the $\mathrm{CO}_{2}$ emissions per capita, whereas the latter variable is significantly correlated to energy use per capita, finance development, and FDI. Figure 1 shows the trend evolution of the different variables. We can observe that a linear relationship between the different variables could exist.

Table 1. Descriptive statistics.

\begin{tabular}{cccccccccc}
\hline Variables & GDPC & GFCF & IMP & FDI & CO2C & EUC & EX & FD & TO \\
\hline Mean & $22,844.0$ & 30.65 & 30.39 & 1.18 & 14.86 & 4300.6 & 47.22 & 22.50 & 77.62 \\
Median & $19,361.5$ & 22.45 & 30.41 & 0.86 & 14.43 & 4448.9 & 46.36 & 21.06 & 75.61 \\
Maximum & $39,125.4$ & 99.70 & 47.67 & 8.49 & 19.52 & 8197.8 & 99.70 & 58.11 & 120.61 \\
Minimum & $15,608.7$ & 17.30 & 13.20 & -8.21 & 9.80 & 977.6 & 26.70 & 2.75 & 56.08 \\
Std. Dev. & 7255.0 & 18.89 & 7.23 & 3.01 & 2.59 & 1846.0 & 14.15 & 14.32 & 12.90 \\
Skewness & 1.22 & 1.81 & 0.04 & 0.06 & -0.005 & -0.111 & 1.11 & 0.51 & 0.69 \\
Kurtosis & 2.90 & 5.63 & 2.81 & 4.40 & 2.032 & 2.68 & 5.21 & 2.61 & 3.85 \\
Observations & 46 & 46 & 46 & 46 & 46 & 46 & 46 & 46 & 46 \\
\hline
\end{tabular}

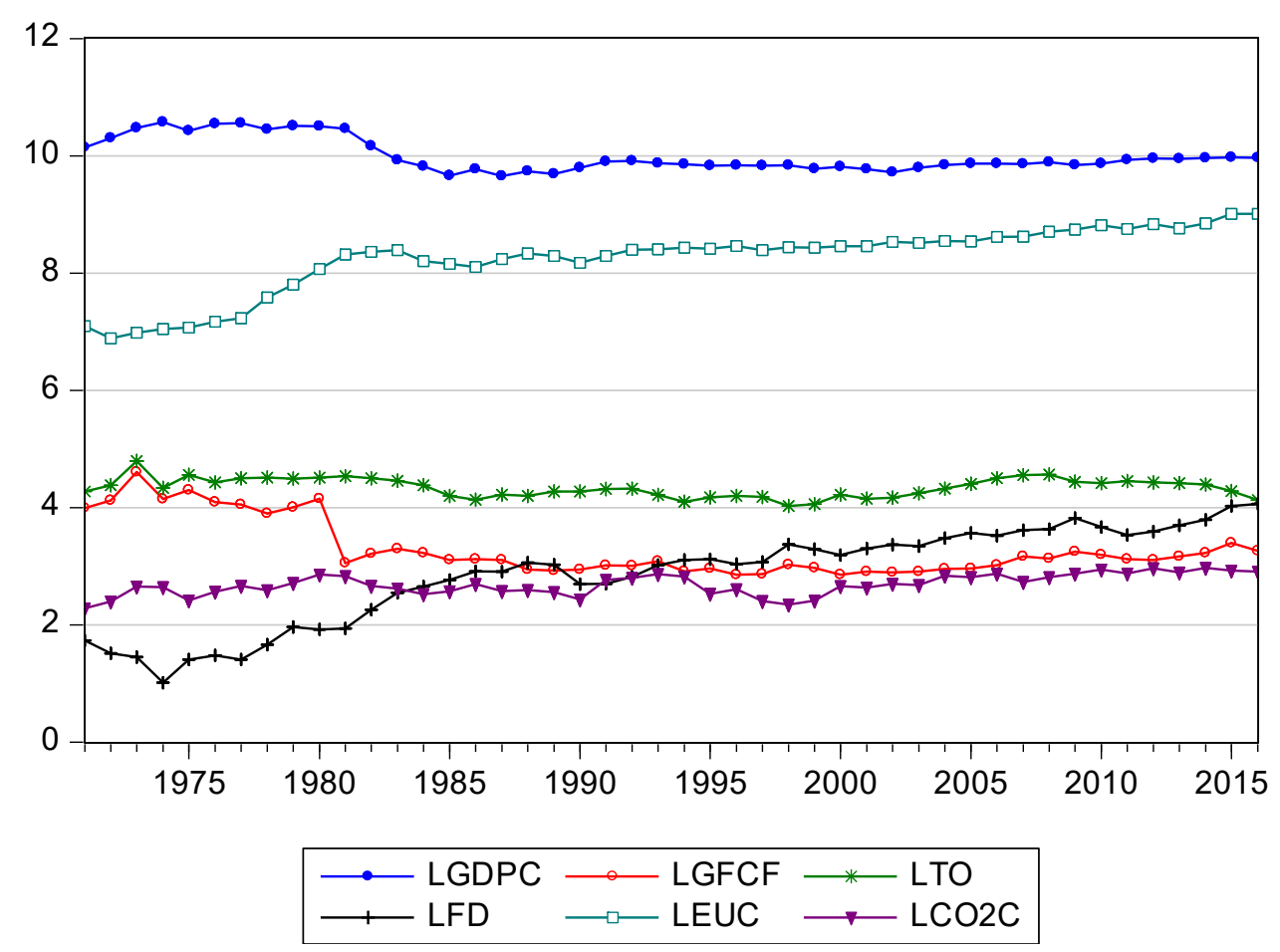

Figure 1. Trend evolution of the different variables. 
Table 2. Matrix of correlation.

\begin{tabular}{|c|c|c|c|c|c|c|c|c|c|}
\hline $\begin{array}{c}\text { Correlation t-Statistic } \\
\text { Probability }\end{array}$ & GDPC & GFCF & IMP & FDI & $\mathrm{CO} 2 \mathrm{C}$ & EUC & EX & FD & TO \\
\hline \multirow{3}{*}{ GDPC } & 1 & & & & & & & & \\
\hline & - & & & & & & & & \\
\hline & - & & & & & & & & \\
\hline \multirow{3}{*}{ GFCF } & 0.84 * & 1 & & & & & & & \\
\hline & 10.4 & - & & & & & & & \\
\hline & 0.00 & - & & & & & & & \\
\hline \multirow{3}{*}{ IMP } & $-0.27^{* * *}$ & $-0.35 *$ & 1 & & & & & & \\
\hline & -1.88 & -2.50 & - & & & & & & \\
\hline & 0.06 & 0.00 & - & & & & & & \\
\hline \multirow{3}{*}{ FDI } & $-0.28 *$ & $-0.36^{*}$ & $0.49^{*}$ & 1 & & & & & \\
\hline & -1.97 & -2.58 & 3.72 & - & & & & & \\
\hline & 0.00 & 0.00 & 0.00 & - & & & & & \\
\hline \multirow{3}{*}{$\mathrm{CO} 2 \mathrm{C}$} & -0.07 & -0.22 & 0.22 & $0.24^{* * *}$ & 1 & & & & \\
\hline & -0.49 & -1.52 & 1.55 & 1.66 & - & & & & \\
\hline & 0.62 & 0.13 & 0.12 & 0.10 & - & & & & \\
\hline \multirow{3}{*}{ EUC } & $-0.63 *$ & -0.70 * & $0.30^{* *}$ & $0.44 *$ & 0.67 * & 1 & & & \\
\hline & -5.41 & -6.51 & 2.15 & 3.25 & 6.05 & - & & & \\
\hline & 0.00 & 0.00 & 0.03 & 0.00 & 0.00 & - & & & \\
\hline \multirow{3}{*}{ EX } & $0.68^{*}$ & $0.73 *$ & $-0.42 *$ & -0.02 & 0.09 & $-0.37^{*}$ & 1 & & \\
\hline & 6.20 & 7.10 & -3.08 & -0.17 & 0.64 & -2.69 & - & & \\
\hline & 0.00 & 0.00 & 0.00 & 0.86 & 0.52 & 0.00 & - & & \\
\hline \multirow{3}{*}{ FD } & $-0.060 *$ & $-0.56^{*}$ & $0.49 *$ & $0.39 *$ & $0.60^{*}$ & 0.93 * & $-0.30 * *$ & 1 & \\
\hline & -5.01 & -4.57 & 3.72 & 2.79 & 5.01 & 17.4 & -2.12 & - & \\
\hline & 0.00 & 0.00 & 0.00 & 0.00 & 0.00 & 0.00 & 0.03 & - & \\
\hline \multirow{3}{*}{ TO } & 0.59 * & $0.60 *$ & 0.09 & $0.24^{* * *}$ & 0.23 & $-0.24^{* * *}$ & $0.86 *$ & $-0.24 * * *$ & 1 \\
\hline & 4.93 & 5.02 & 0.65 & 1.68 & 1.59 & -1.64 & 11.22 & -1.68 & - \\
\hline & 0.00 & 0.00 & 0.51 & 0.09 & 0.11 & 0.10 & 0.00 & 0.10 & - \\
\hline
\end{tabular}

Note: ${ }^{*}, * * * *$ Level of significance at $1 \%, 5 \%$, and $10 \%$, respectively.

\subsection{Estimated Models}

\subsubsection{Economic Growth Model}

In order to check the impact of trade openness on economic growth in Saudi Arabia, we perform the following econometric model:

$$
\mathrm{LGDPC}_{\mathrm{t}}=\beta_{0}+\gamma_{\mathrm{t}}+\beta_{1} \mathrm{LEUC}_{\mathrm{t}}+\beta_{2} \mathrm{LGFCF}_{\mathrm{t}}+\beta_{3} \mathrm{FD}_{\mathrm{t}}+\beta_{4} \mathrm{LFDI}_{\mathrm{t}}+\beta_{5} \mathrm{LTO}_{\mathrm{t}}+\varepsilon_{\mathrm{t}}
$$

where $\mathrm{L}$ is the natural logarithm, $\mathrm{t}$ is a time trend that takes the years from 1971 to 2016, GDPC is the GDP per capita (at constant 2010 US\$), EUC is the energy consumption per capita (kg oil equivalent), GFCF is the gross fixed capital formation as a percentage of GDP that represents a domestic investment, FD is the finance development, FDI is the net inwards of foreign direct investment as a percentage of GDP, TO is trade openness, and $\varepsilon_{\mathrm{t}}$ is the error term. The main objective of log transformation is to make highly skewed distributions less skewed. This can be valuable both for making patterns in the data more interpretable and for helping to meet the assumptions of inferential statistics. The non-logarithmization of FDI is due to its negative values in certain years. This cannot affect the results and their interpretation. Moreover, we do not address the problem of multicollinearity, which can be expected in the case of GDPC and GFCF. Multicollinearity in the ARDL model is not important. It is natural because there is much endogeneity. Besides, we focus in this study on the results of trade openness and not GFCF.

The various variables are chosen based on previous literature reviews, such as the studies of Alalaya [41], Alhowaish [32], Altaee et al. [33], Fetahi-Vehapi et al. [27], Gokmenoglu et al. [29], Cetin [36], Fayyaz et al. [39], and Kong et al. [40]. For a robustness check, three indicators capture the trade openness variable: The share of exports plus imports in GDP, the share of exports in GDP, and the share of imports in GDP. GFCF is the physical capital accumulation, which represents an important determinant of growth [6]. Firms can accumulate knowledge through capital accumulation, and thus, investments can promote economic growth. It is expected to have a positive effect. Energy use plays the role natural factor of production [65]. FDI is considered to potentially bring a positive impact on Saudi 
economic growth. Finance development is proxied by the ratio of credit accorded to private sector to GDP. It is expected to positively affect economic growth. Finally, we expect that trade openness will have a mixed impact on economic growth.

The unrestricted error correction model (UECM) form of the economic growth model (Equation (1)) is given by the following $\operatorname{ARDL}(p, q, r, s, u, v)$ :

$$
\begin{aligned}
& \mathrm{D}\left(\mathrm{LGDPC}_{\mathrm{t}}=\beta_{0}+\gamma_{\mathrm{t}}+\alpha_{0} \mathrm{LGDPC}_{\mathrm{t}-1}+\alpha_{1} \mathrm{LEUC}_{\mathrm{t}-1}\right. \\
& +\alpha_{2} \mathrm{LGFCF}_{\mathrm{t}-1}+\alpha_{3} \mathrm{FD}_{\mathrm{t}-1}+\alpha_{4} \mathrm{LFDI}_{\mathrm{t}-1}+\alpha_{5} \mathrm{LTO}_{\mathrm{t}-1}+ \\
& \sum_{i=1}^{\mathrm{p}} \mathrm{D}(\mathrm{LGDPC})_{\mathrm{t}-i}+\sum_{i=0}^{\mathrm{q}} \pi_{\mathrm{i}} \mathrm{D}\left(\mathrm{LEUC}_{\mathrm{t}-i}+\right. \\
& \sum_{i=0}^{\mathrm{r}} v_{\mathrm{i}} \mathrm{D}(\mathrm{LGFCF})_{\mathrm{t}-i}+\sum_{i=0}^{\mathrm{s}} \tau_{\mathrm{i}} D(\mathrm{LFD})_{\mathrm{t}-i} \\
& +\sum_{i=0}^{\mathrm{u}} \rho_{i} \mathrm{D}(\mathrm{LFDI})_{\mathrm{t}-i}+\sum_{i=0}^{\mathrm{v}} \varphi_{i} \mathrm{D}(\mathrm{LTO})_{\mathrm{t}-i}+\mathrm{\kappa}_{\mathrm{t}}
\end{aligned}
$$

where $\mathrm{D}$ is the first difference operator; $\mathrm{t}$ is the years from 1971 to 2016 that will take into account the trend evolution and the structural change in time; $\mathrm{p}, \mathrm{q}, \mathrm{r}, \mathrm{s}, \mathrm{u}$ and $\mathrm{v}$ are the maximum lag orders, and $\mathrm{k}_{\mathrm{t}}$ is the error term. This model determines both the short- and long-term estimates.

\subsubsection{Environmental Quality Model}

The environmental quality model is mainly adopted from those proposed by Ridzuan et al. [38] and Chandia et al. [3]. Its logarithmic form is given by the following equation:

$$
\mathrm{LCO}_{\mathrm{t}}=\beta_{0}+\beta_{1} \mathrm{LEUC}_{\mathrm{t}}+\beta_{2} \mathrm{LGDPC}_{\mathrm{t}}+\beta_{3} \mathrm{FD}_{\mathrm{t}}+\beta_{4} \mathrm{LFDI}_{\mathrm{t}}+\beta_{5} \mathrm{LTO}_{\mathrm{t}}+\varepsilon_{\mathrm{t}}
$$

where $\mathrm{CO}_{2}$ emissions per capita $\left(\mathrm{CO}_{2}\right)$ (expressed in metric tons) are explained by energy use per capita, real GDP per capita, finance development, FDI, and trade openness. Environmental quality is approached by $\mathrm{CO}_{2}$ emissions per capita. Both energy consumption and economic activity are proved by the literature that are the main natural drivers of $\mathrm{CO}_{2}$ emissions. Energy use per capita is expected to have a positive impact on $\mathrm{CO}_{2}$ as Saudi Arabia is among the top ten consumers of energy. In addition, it is expected that GDP per capita has a positive impact on $\mathrm{CO}_{2}$ emissions per capita. FDI, FD and TO are expected to have mixed signs.

The unrestricted error correction ARDL ( $\mathrm{p}, \mathrm{q}, \mathrm{r}, \mathrm{s}, \mathrm{u}, \mathrm{v}$ ) form of the environmental quality model given in Equation (3) is written as follows:

$$
\begin{aligned}
& \mathrm{D}(\mathrm{LCO} 2)_{\mathrm{t}}=\beta_{0}+\alpha_{0} \mathrm{LCO}_{\mathrm{t}-1}+\alpha_{1} \mathrm{LEUC}_{\mathrm{t}-1} \\
& +\alpha_{2} \mathrm{LGDPC}_{\mathrm{t}-1}+\alpha_{3} \mathrm{FD}_{\mathrm{t}-1}+\alpha_{4} \mathrm{LFDI}_{\mathrm{t}-1}+\alpha_{5} \mathrm{LTO}_{\mathrm{t}-1}+ \\
& \sum_{i=1}^{\mathrm{p}} \gamma_{i} \mathrm{D}(\mathrm{LCO} 2)_{\mathrm{t}-i}+\sum_{i=0}^{\mathrm{q}} \pi_{\mathrm{i}} \mathrm{D}\left(\mathrm{LEUC}_{\mathrm{t}-i}+\right. \\
& \sum_{i=0}^{\mathrm{r}} v_{\mathrm{i}} D(\mathrm{LGDPC})_{\mathrm{t}-i}+\sum_{i=0}^{s} \tau_{\mathrm{i}} \mathrm{D}(\mathrm{LFD})_{\mathrm{t}-i}+ \\
& \sum_{i=0}^{\mathrm{u}} \rho_{i} \mathrm{D}(\mathrm{LFDI})_{\mathrm{t}-i}+\sum_{i=0}^{\mathrm{v}} \varphi_{i} \mathrm{D}(\mathrm{LTO})_{\mathrm{t}-i}+\kappa_{\mathrm{t}}
\end{aligned}
$$

where $D$ is the first difference operator; $t$ is the years from 1971 to 2016; $p, q, r, s, u$ and $v$ are the maximum lag orders, and $\kappa_{\mathrm{t}}$ is the error term.

The ARDL bounds test for cointegration of Pesaran et al. [64] is initiated for determining the existence of long-term relationships between the various variables considered in our models. This test checks the null hypothesis, $H_{0}: \alpha_{0}=\alpha_{1}=\alpha_{2}=\alpha_{3}=\alpha_{4}=\alpha_{5}=0$, given respectively, in Equations (2) and (4). The rejection of the null hypothesis implies the presence of cointegration among the variables. The output of this test depends on the F-statistic value. If the estimated F-statistic value is higher than the upper bound critical value (I(1)), we can reject the null hypothesis, and thus, the variables are cointegrated. Whereas, when F-statistic is lower than the lower critical bound $(\mathrm{I}(0))$, we cannot reject the null hypothesis of the existence of cointegration. 


\section{Results and Discussion}

We begin the interpretation of our results by presenting the results of unit root tests for the various time series investigated in this study. The unit root tests are initiated for both levels and first differences of the variables. The results of the three unit root tests (ADF, PP, and DF-GLS) are shown in Table 3. We find that none of the variables is integrated of order two. They are stationary at their levels or at their first differences. Thus, they are either integrated of order zero or one. We obtain similar results for the three conventional unit root tests. Therefore, our findings can be robust, and they suggest the use of the ARDL bounds test to cointegration technique without doubt.

Table 3. Results of unit root tests.

\begin{tabular}{|c|c|c|c|c|c|c|c|}
\hline \multirow{2}{*}{ Variables } & \multicolumn{2}{|c|}{ ADF Test } & \multicolumn{2}{|c|}{ PP Test } & \multicolumn{2}{|c|}{ DF-GLS Test } & \multirow{2}{*}{ Order of Integration } \\
\hline & Level & First Difference & Level & First Difference & Level & First Difference & \\
\hline LGDPC & $-2.42(2)$ & $-5.23(1) *$ & $-0.26(1)$ & $-5.24(1) *$ & $-2.30(3)$ & $-2.25(2) * *$ & $\mathrm{I}(1)$ \\
\hline LIMP & $-2.7(2)^{* * *}$ & $-7.10(1)$ * & $-2.68(2)^{* * *}$ & $-7.21(1)^{*}$ & $-2.30(3)$ & $-7.09(2)$ * & $\mathrm{I}(0)$ or $\mathrm{I}(1)$ \\
\hline FDI & $-3.25(1)$ * & $-8.50(1)^{*}$ & $-3.21(1) *$ & $-10.35(1)$ * & $-3.91(3)^{*}$ & $-7.77(1)$ * & $\mathrm{I}(0)$ \\
\hline $\mathrm{LCO} 2 \mathrm{C}$ & $-2.94(2)^{* *}$ & $-7.35(1)$ * & $-2.95(2)^{* *}$ & $-7.61(1)^{*}$ & $-3.09(3)^{* * *}$ & $-6.63(2)$ * & $\mathrm{I}(0)$ or $\mathrm{I}(1)$ \\
\hline LEUC & $-3.15(3)$ & $-5.24(2)$ * & $1.96(1)$ & $-4.60(1)$ * & $-1.35(3)$ & $-2.97(2)$ * & $\mathrm{I}(1)$ \\
\hline LTO & $-0.26(1)$ & $-9.13(1) *$ & $-2.52(2)$ & $-9.24(1)$ * & $-1.96(3)$ & $-8.18(2)$ * & $\mathrm{I}(1)$ \\
\hline
\end{tabular}

Note: (1) The Schwarz Information Criterion (SIC) is used to choose the optimal lag length, and the maximum lag length is set to nine in the case of ADF and DF-GLS tests. 2. The values between parentheses are the optimal lag length used. 3. The Bandwidth is selected using the Newey-West method for the case of PP test. $4 .{ }^{*}, * *, * * *$ Level of significance at $1 \%, 5 \%$, and $10 \%$, respectively.

In the second step of the analysis, we estimate the ARDL models given by Equations (2) and (4) to detect if there is a cointegration relationship between the variables by performing the ARDL bounds F-test for cointegration of Pesaran. We estimate three versions of the economic growth model (model 1, model 2, and model 3). We also estimate three versions of the environmental quality model (model 1, model 2, and model 3). In model 1, the variable trade openness is proxied by the ratio of exports plus imports to GDP, while it is proxied by the share of exports in GDP and the ratio of imports to GDP in models 2 and 3, respectively. Economic growth models are estimated with an unrestricted constant and restricted trend, whereas environmental quality models are estimated with only an unrestricted constant. The results of the ARDL bounds F-test are displayed in Table 4. We find that all the values of $F$-statistics are greater than the upper bound critical values $(\mathrm{I}(1))$ at even a $1 \%$ significance level. Hence, we conclude the presence of cointegration relationship among the various variables for the case of all models considered.

Table 4. Results of autoregressive distributed lag (ARDL) Bounds test.

\begin{tabular}{|c|c|c|c|c|c|}
\hline Model & & Max. Lag & ARDL Lag Order & F-Statistic & $\mathbf{k}$ \\
\hline \multirow{3}{*}{ Economic growth model } & Model 1 & 4 & $\operatorname{ARDL}(4,2,4,1,4,2)$ & 7.64 & 5 \\
\hline & Model 2 & 4 & $\operatorname{ARDL}(4,1,2,4,4,2)$ & 13.31 & 5 \\
\hline & Model 3 & 4 & $\operatorname{ARDL}(1,4,3,4,3,4)$ & 9.39 & 5 \\
\hline \multirow{3}{*}{$\begin{array}{l}\text { Environmental quality } \\
\text { model }\end{array}$} & Model 1 & 4 & $\operatorname{ARDL}(4,4,3,3,4,4)$ & 6.42 & 5 \\
\hline & Model 2 & 4 & $\operatorname{ARDL}(4,4,4,4,0,4)$ & 5.33 & 5 \\
\hline & Model 3 & 4 & $\operatorname{ARDL}(4,4,1,3,0,0)$ & 5.01 & 5 \\
\hline & \multicolumn{2}{|c|}{$\begin{array}{l}\text { Case 4: Unrestricted Constant } \\
\text { and Restricted Trend }\end{array}$} & \multicolumn{3}{|c|}{ Case 3: Unrestricted Constant and No Trend } \\
\hline Levels of significance & $\mathrm{I}(0)$ & $\mathrm{I}(1)$ & $\mathrm{I}(0)$ & \multicolumn{2}{|c|}{$\mathrm{I}(1)$} \\
\hline $10 \%$ & 2.49 & 3.38 & 2.26 & \multicolumn{2}{|c|}{3.35} \\
\hline $5 \%$ & 2.81 & 3.76 & 2.62 & \multicolumn{2}{|c|}{3.79} \\
\hline $1 \%$ & 3.5 & 4.63 & 3.41 & \multicolumn{2}{|c|}{4.68} \\
\hline
\end{tabular}

Note: (1) $k$ is the number of dynamic regressors. (2) The model selection method is the Akaike info criterion (AIC). 3. The null hypothesis is the absence of a relationship.

Thirdly, we estimate the error correction models to determine the short- and long-term coefficients. To do so, it is important to check for the validity of the estimated models by performing a battery of 
diagnostic tests, such as the normality tests, the serial correlation tests, and the tests of the absence of heteroscedasticity of error terms. We present the results of these different tests in Table 5. They indicate that the error terms are normally distributed, not correlated and not heteroscedastic as all p-values are largely higher than $5 \%$. Thus, all models pass without issue. Besides, we check for the stability of the models by performing the cumulative sum of recursive residuals (CUSUM) and the cumulative sum of the square of recursive residuals (CUSUMSQ) tests. We display their results in Figure 2. We observe that the coefficients of the six models are stable because the blue line usually lies between both red lines. Thus, we can say that our estimated models are stable. Hence, our findings are robust and can be analyzed without caution.

Table 5. Results of diagnostic tests for ARDL models.

\begin{tabular}{|c|c|c|c|c|c|c|c|}
\hline & & \multicolumn{3}{|c|}{ Economic Growth Model } & \multicolumn{3}{|c|}{ Environmental Quality Model } \\
\hline & & Model 1 & Model 2 & Model 3 & Model 1 & Model 2 & Model 3 \\
\hline Normality test & $\begin{array}{c}\text { Jarque-Bera stat. } \\
(p \text {-value })\end{array}$ & $0.773(0.67)$ & $1.204(0.54)$ & $0.493(0.78)$ & $0.989(0.61)$ & $0.135(0.93)$ & $0.042(0.97)$ \\
\hline $\begin{array}{c}\text { Breusch-Godfrey Serial } \\
\text { Correlation LM Test }\end{array}$ & F-stat. ( $p$-value) & $1.342(0.26)$ & $0.338(0.56)$ & $0.076(0.78)$ & $1.470(0.24)$ & $0.257(0.61)$ & $0.696(0.41)$ \\
\hline $\begin{array}{l}\text { Breusch-Pagan-Godfrey } \\
\text { Heteroskedasticity Test }\end{array}$ & F-stat. ( $p$-value) & $0.923(0.57)$ & $1.019(0.48)$ & $0.575(0.89)$ & $1.205(0.36)$ & $1.692(0.13)$ & $1.124(0.38)$ \\
\hline
\end{tabular}

Now we turn to present the results of the estimation of the error correction models, which are respectively reported in Tables 6 and 7. It is indicated in Table 6 that the coefficient of the lagged error correction term (ECT(-1)) is negative and significant in the case of the six models. This confirms the presence of cointegration relationship among all the variables for all the models investigated. Besides, the speed of adjustment to the equilibrium is rapid because it is greater than $100 \%$ for all models.

Table 6. Short-term elasticities and error correction term estimates.

\begin{tabular}{|c|c|c|c|c|c|c|c|}
\hline \multicolumn{4}{|c|}{ Economic Growth Model (D(LGDPC)) } & \multicolumn{4}{|c|}{ Environmental Quality Model (D(LCO2)) } \\
\hline \multirow{2}{*}{ Variables } & Model 1 & Model 2 & Model 3 & \multirow{2}{*}{ Variables } & Model 1 & Model 2 & Model 3 \\
\hline & & efficient $(p$-Valu & & & \multicolumn{3}{|c|}{ Coefficient ( $p$-Value) } \\
\hline D(LEUC) & $0.184^{* *}(0.03)$ & $0.110^{* * *}(0.08)$ & $-0.071(0.40)$ & D(LEUC) & $0.353^{* *}(0.04)$ & $0.552 *(0.00)$ & $0.361^{* *}(0.02)$ \\
\hline $\mathrm{D}$ (LGFCF) & $0.297 *(0.00)$ & $0.215 *(0.00)$ & $0.112 * *(0.02)$ & D(LGDPC) & $1.316 *(0.00)$ & $0.867 *(0.00)$ & $1.416 *(0.00)$ \\
\hline $\mathrm{D}(\mathrm{LFD})$ & $-0.452 *(0.00)$ & $-0.381 *(0.00)$ & $-0.292 *(0.00)$ & $\mathrm{D}(\mathrm{LFD})$ & $0.021(0.87)$ & $-0.37^{* *}(0.02)$ & $-0.096(0.42)$ \\
\hline $\mathrm{D}(\mathrm{FDI})$ & $0.019 *(0.00)$ & $0.024 *(0.00)$ & $0.009 *(0.01)$ & $\mathrm{D}(\mathrm{FDI})$ & $-0.006(0.39)$ & - & - \\
\hline D(LTO) & $-0.074(0.39)$ & - & - & D(LTO) & $0.283(0.14)$ & - & - \\
\hline D(LEX) & - & $0.033(0.47)$ & - & D(LEX) & - & $-0.245(0.08)$ & - \\
\hline D(LIMP) & - & - & $0.003(0.95)$ & D(LIMP) & - & - & - \\
\hline ECT(-1) & $-1.683 *(0.00)$ & $-1.311 *(0.00)$ & $-1.061 *(0.00)$ & $\mathrm{ECT}(-1)$ & $-1.54 *(0.00)$ & $-1.22 *(0.00)$ & \\
\hline R-squared & 0.91 & 0.94 & 0.92 & R-squared & 0.87 & 0.84 & 0.73 \\
\hline $\begin{array}{l}\text { Adjusted } \\
\text { R-squared }\end{array}$ & 0.85 & 0.90 & 0.85 & $\begin{array}{c}\text { Adjusted } \\
\text { R-squared }\end{array}$ & 0.72 & 0.69 & 0.62 \\
\hline
\end{tabular}

Note: ECT(-1) is the lagged error correction term; ${ }^{*}, * *{ }^{* * *}$ Level of significance at $1 \%, 5 \%$, and $10 \%$, respectively; the values between parentheses are $p$-values.

Table 7. Long-term elasticities estimates.

\begin{tabular}{|c|c|c|c|c|c|c|c|}
\hline \multicolumn{4}{|c|}{ Economic Growth Model } & \multicolumn{4}{|c|}{ Environmental Quality Model } \\
\hline \multirow{2}{*}{ Variables } & Model 1 & Model 2 & Model 3 & \multirow{2}{*}{ Variables } & Model 1 & Model 2 & Model 3 \\
\hline & \multicolumn{3}{|c|}{ Coefficient ( $p$-Value) } & & \multicolumn{3}{|c|}{ Coefficient ( $p$-Value) } \\
\hline LEUC & $0.287 *(0.00)$ & $0.214 *(0.00)$ & $-0.465^{* *}(0.02)$ & LEUC & $0.566 *(0.00)$ & $0.952 *(0.00)$ & $0.610 *(0.00)$ \\
\hline LGFCF & $0.282 *(0.00)$ & $0.278 *(0.00)$ & $-0.039(0.71)$ & LGDPC & $0.150(0.32)$ & $\begin{array}{c}-0.655^{* * *} \\
(0.09)\end{array}$ & $0.624 *(0.00)$ \\
\hline LFD & $-0.769 *(0.00)$ & $-0.888 *(0.00)$ & $-0.813 *(0.00)$ & LFD & $-0.163(0.14)$ & $-0.602 *(0.00)$ & $-0.156(0.17)$ \\
\hline FDI & $0.014^{* *}(0.02)$ & $0.017 *(0.01)$ & $-0.006(0.30)$ & FDI & $-0.015(0.29)$ & $-0.013(0.26)$ & $0.006(0.32)$ \\
\hline LTO & $-0.234^{* *}(0.02)$ & - & - & LTO & $0.818 *(0.00)$ & - & - \\
\hline LEX & - & $-0.270^{*}(0.00)$ & - & LEX & - & $0.841 *(0.00)$ & - \\
\hline LIMP & - & - & $0.428 *(0.00)$ & LIMP & - & - & $0.231 *(0.00)$ \\
\hline Trend & $0.025 *(0.00)$ & $0.034 *(0.00)$ & $0.050 *(0.00)$ & & & & \\
\hline
\end{tabular}

Note: ${ }^{* * *}, * * *$ Level of significance at $1 \%, 5 \%$, and $10 \%$, respectively; the values between parentheses are $p$-values. 
Economic growth model 1
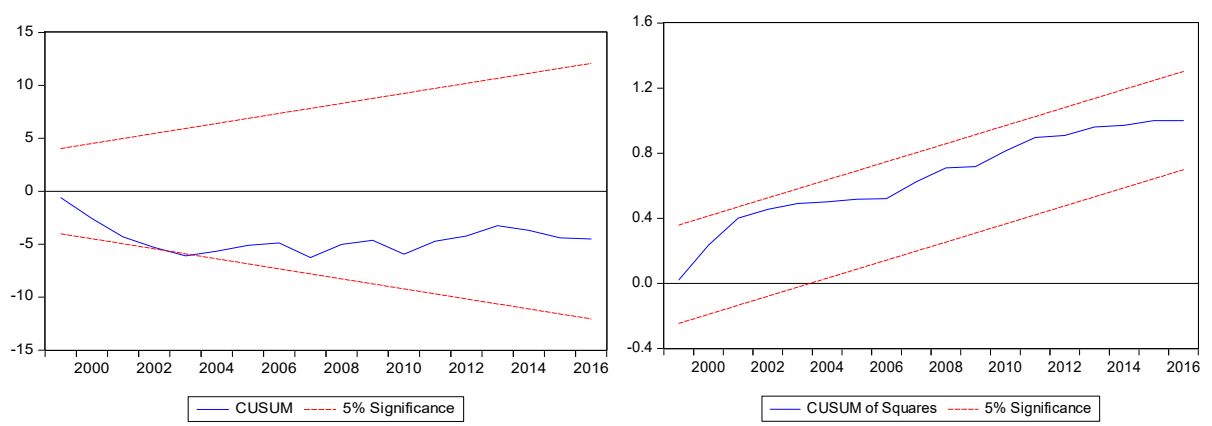

Economic growth model 2
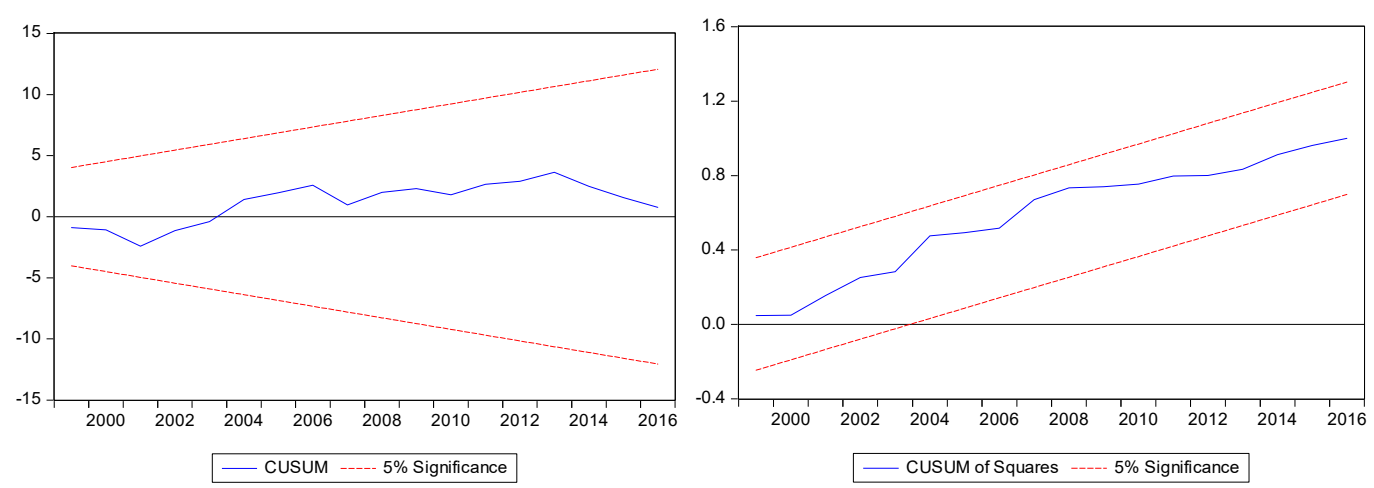

Economic growth model 3
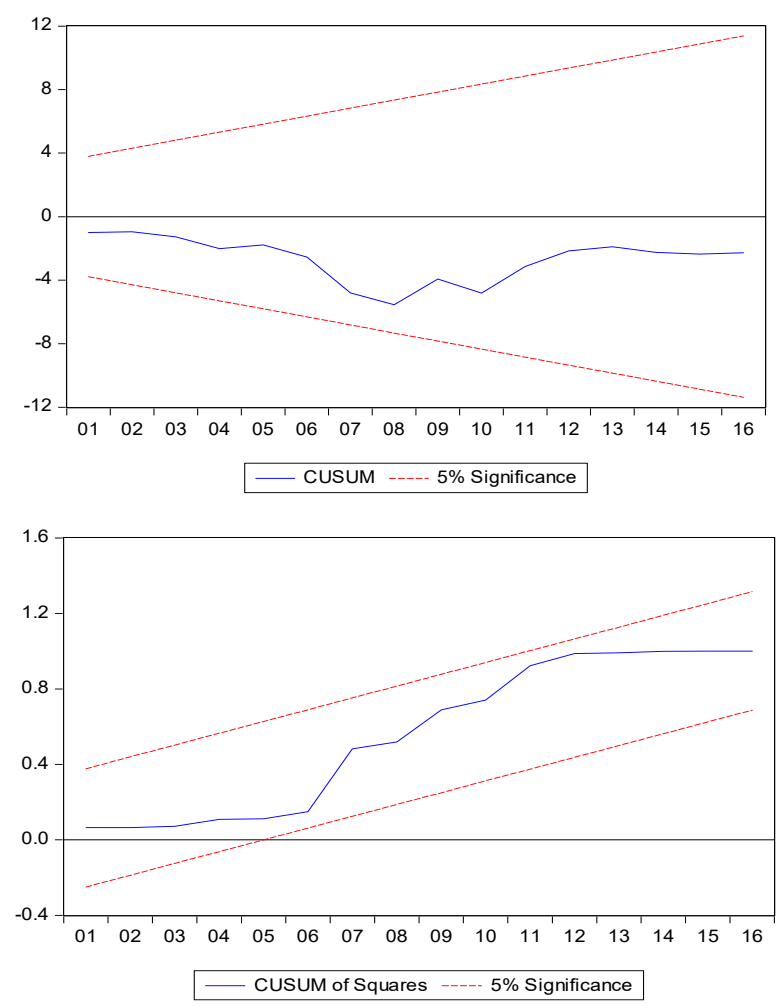

Figure 2. Cont. 
Environmental quality model 1
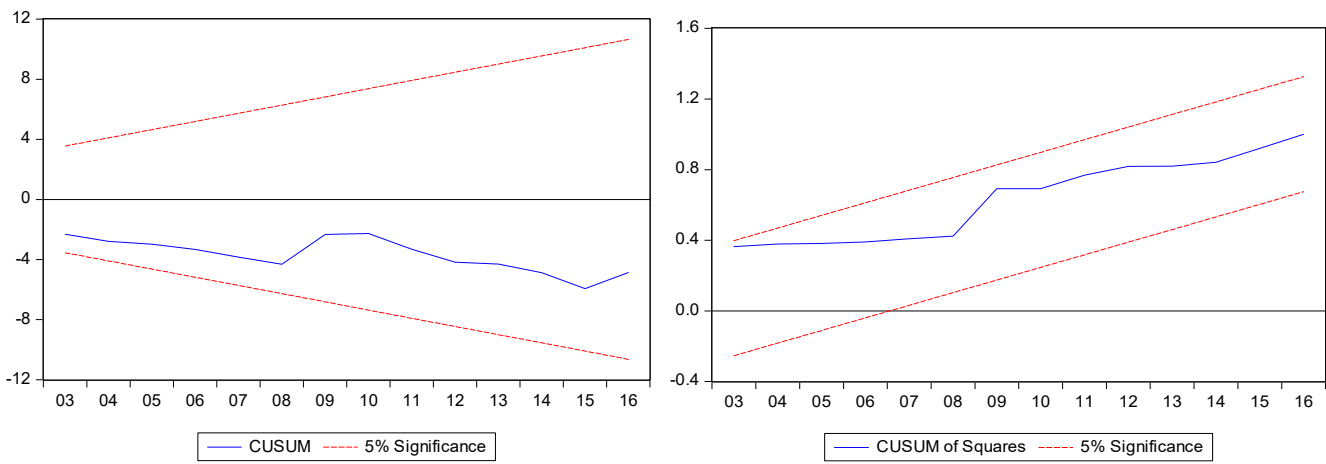

Environmental quality model 2
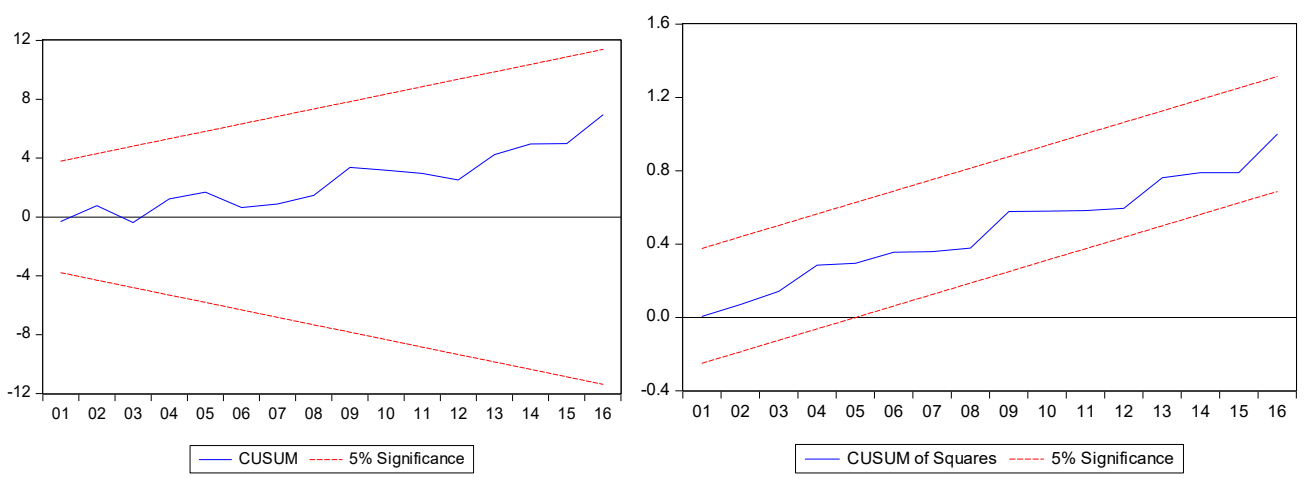

Environmental quality model 3
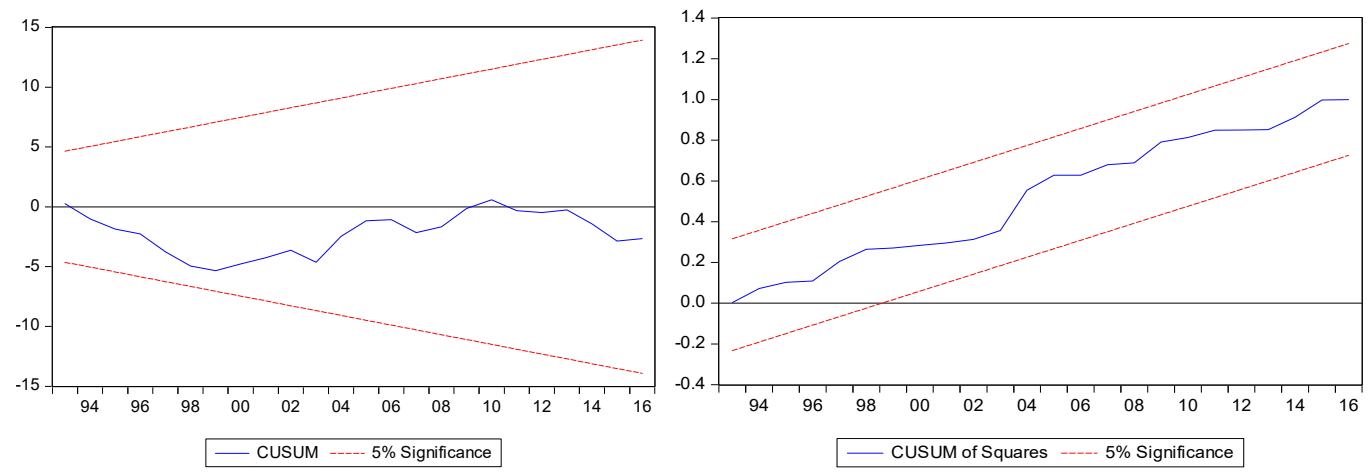

Figure 2. The cumulative sum of recursive residuals (CUSUM) and CUSUM of Squares.

For the case of economic growth models, we find that the short-term elasticity of energy consumption has a positive sign, and it is significant with respectively $5 \%$ and $10 \%$ levels of significance for models 1 and 2. The long-term elasticity of energy use is positive and significant at $1 \%$ level for models 1 and 2, while it has a negative sign, and it is significant at $5 \%$ for the case of model 3 . Overall, these findings suggest that energy use boosts Saudi economic growth in both the short- and long-term. Hence, our results confirm the findings of the majority of previous empirical studies, which have indicated that energy consumption is not neutral to economic growth as suggested by the neoclassical growth theory. The short-term elasticity of domestic investment is usually positive and significant at $5 \%$ for the three models, whereas its long-term elasticity is positive and significant at $1 \%$ for the models 1 and 2 . Thus, we can deduce that domestic investment plays its role in creating economic output, and through increasing economic activity in both the short- and long-term for Saudi Arabia. These results of domestic investment are expected, and they conform to the economic theory. We also obtain the same results for foreign direct investment in the short-term. It is 
shown that the coefficient of FDI is usually positive and significant at $1 \%$ for the three models in the short-term, whereas it is not significant at all in the long-term. Thus, the FDI-led growth hypothesis is validated in the short-term for Saudi Arabia. This suggests that foreign direct investment can boost Saudi economic growth in only the short-term. This result may be induced by the implementation of trade liberalization policies. However, the absence of FDI effect in the long-term may be caused by the non-existence of high skilled workers, and the deficiencies in the financial and market systems.

For the variable finance development, we find that its elasticity is usually negative and significant at $1 \%$ for the three models in both the short- and long-term. Thus, we can deduce that finance development negatively affects Saudi Arabia's economic growth. This finding is not in line with those of Hermes and Lensink [66], Durham [67], Alfaro et al. [68] and Ridzuan et al. [38] who find that countries with better financial systems and financial market regulations can exploit FDI more efficiently and achieve a higher economic growth rate. Therefore, Saudi Arabia's financial systems demand better regulation and organization to be more efficient. Finally, our findings infirm the hypothesis that states that trade openness promotes economic growth. Overall, our results indicate that openness to international trade does not lead to enhance economic growth in Saudi Arabia. In fact, we find that the short-term elasticity of trade openness is insignificant in all three models. Nevertheless, the long-term elasticity of trade openness is negative and significant in models 1 and 2 with respectively, $5 \%$ and $1 \%$ levels of significance, whereas it is positive and significant at $1 \%$ in model 3 . These results imply that trade openness does not affect Saudi Arabia's economic growth in the short-term, whereas it may have positive or negative impacts in the long-term. When the ratio of exports plus imports to GDP increases by $10 \%$, economic growth will decline by approximately $2.34 \%$ in the long-term, whereas if the ratio of exports to GDP increases by 10\%, long-term economic growth will decrease by $2.7 \%$ in Saudi Arabia. This may be explained by the Dutch disease effect of oil exports on the non-oil Saudi Arabia's economic activities. However, if the ratio of imports to GDP rises by $10 \%$, Saudi economic growth will increase by $4.28 \%$ in the long-term. The results of trade openness given by models 1 and 2 conform to those of Kim and Lin [69] who show that trade openness positively affects economic growth for developed countries, but it can have negative impacts for developing countries. In addition, Trejos and Barboza [70] find that trade openness is not an essential catalyzer of economic growth in Asia. The positive impact of imports on Saudi Arabia's economic growth in may be due to three channels that are importation of intermediate inputs and technologies, an increase of market sizes for new product varieties, and diffusion of general knowledge and innovation [71]. The positive impact of imports on economic growth conforms to previous findings of Wacziarg and Welch [72], Squalli and Wilson [73], Sakyi et al. [74] and Ridzuan et al. [38].

In the case of environmental quality models, it is found that the short-term and long-term elasticities of energy consumption are positive and significant at $5 \%$ for the three models. These findings indicate that energy use is one of the main forces of pollution in Saudi Arabia. The short-term elasticity of GDP per capita is usually positive and significant at $1 \%$ for the three models while its long-term elasticity is positive and significant at $1 \%$ in model 3 and negative and significant at $10 \%$ in model 2 . These findings indicate that economic growth leads to an increase in the levels of pollution in the short-term, whereas it may have a positive, neutral or negative impact on the environment in the long-term for Saudi Arabia. These findings conform to the statement that a high level of economic growth necessitates a high level of energy use, and thus, induces a higher level of pollution $[75,76]$. The expansion of the Saudi economy (19th worldwide) has led to environmental degradation. Our results are also obtained by previous empirical studies for the case of Saudi Arabia (e.g., [77,78]).

The coefficients of FDI are insignificant in both the short- and long-term in all models. These findings show that foreign direct investments inflows do not affect the environment in Saudi Arabia. The short-term and long-term elasticities of finance development are negative and significant at $5 \%$ in only model 2. This indicates that finance development may lead to reduce $\mathrm{CO}_{2}$ emissions in both the short- and long-term. Thus, it has a positive impact on the environment for Saudi Arabia. Finally, our results support the hypothesis stating that openness to international trade is harmful to the 
environment in emerging countries, such as Saudi Arabia. Overall, we find that trade openness leads to an increase in $\mathrm{CO}_{2}$ emissions in Saudi Arabia. In fact, it is shown that the short-term elasticity of trade openness is negative and significant at $10 \%$ in only model 2 . However, the long-term elasticity of trade openness is positive and significant at $1 \%$ in the three models. A rise of $10 \%$ in the share of exports in GDP will decline the release of $\mathrm{CO}_{2}$ emissions by $2.45 \%$ in the short-term. If the ratio of exports plus imports to GDP increases by $10 \%, \mathrm{CO}_{2}$ emissions will rise by $8.18 \%$ in the long-term, whereas if the ratio of exports to GDP increases by $10 \%, \mathrm{CO}_{2}$ emissions will rise by $8.41 \%$ in Saudi Arabia. Besides, a rise of $10 \%$ in the ratio of imports to GDP will expand the release of $\mathrm{CO}_{2}$ emissions by $2.31 \%$ in the long-term. These results suggest that trade openness may have a positive impact on the environment in the short-term for Saudi Arabia, but it has a negative impact on the environment in the long-term. Therefore, trade openness leads to an increase in $\mathrm{CO}_{2}$ emissions in the long-term. Thus, it is harmful to the Saudi Arabian environment in the long-term. However, Saudi Arabia's exports leads to a decrease in $\mathrm{CO}_{2}$ emissions in the short-term, implying that exports can be beneficial to the environment. The positive impact of international trade on $\mathrm{CO}_{2}$ emissions in the short-term may be due to its technique effect, whereas its negative impact on $\mathrm{CO}_{2}$ emissions in the long-term may be due the scale effect of international trade or its composition effect or both of them. We can say that the technique effect of international trade outweighs the other effects in the short-term, while the scale effect counterbalances the rest of the effects in the long-term. These results are expected because oil exports represent an important share in all Saudi exports and oil exports are linked to dirty and polluting activities. In addition, these results suggest that Saudi Arabia should import less pollution-intensive products from their trading partners. Moreover, effective environmental regulations should be enforced to reduce environmental pollution in Saudi Arabia.

\section{Conclusions and Policy Implications}

In this paper research, we investigate the effects of trade openness on economic growth and $\mathrm{CO}_{2}$ emissions in Saudi Arabia using the ARDL bounds test to cointegration approach over the period 1971-2016. Both research questions are answered. Firstly, overall, we obtain that openness to international trade does not promote Saudi Arabia's economic growth. In fact, we find that trade openness does not enhance Saudi Arabia's economic growth in the short-term, whereas it may have positive or negative impacts in the long-term. Both variables of the ratio of exports plus imports to GDP and ratio of exports to GDP do not enhance economic growth in the long-term, whereas the variable of the ratio of imports to GDP enhances economic growth in the long-term. The results report that the export-led-growth hypothesis does not hold in both the short- and long-term, whereas the import-led-growth hypothesis is validated in the long-term. Hence, Saudi Arabia's exports do not participate in accelerating economic growth-neither in the short-term, nor in the long-term. Whereas, its imports can boost its economic growth in the long-term. Unexpectedly, trade openness, measured by the percentage of exports plus imports to GDP, is shown to have a negative and significant impact on Saudi Arabia's economic growth in the long-term. This may be explained by the fact that the production capacity of the non-oil sectors is not competitive in Saudi Arabia. Policies based on importing more intermediate and technological products should be reinforced at the expense of consumer goods. This can lead to economic diversification in the Kingdom, increase non-oil economic output and promote non-oil exports to achieve the desired objectives of the Saudi vision 2030.

Secondly, the majority of results of the variables proxy of trade openness indicate that trade openness leads to an increase in $\mathrm{CO}_{2}$ emissions in Saudi Arabia. In fact, trade openness, measured by the share of exports plus imports in GDP or the ratio of exports to GDP or the share of imports in GDP, negatively affects the environmental quality in the long-term for Saudi Arabia. However, Saudi Arabia's exports are favorable to the environment in the short-term. Overall, trade openness could bring unfavorable impact on sustainable development for Saudi Arabia. Besides trade openness, it is also found that finance development could be a favorable driver for environmental quality, but a restricting driver for economic growth. Whereas, FDI could be a favorable driver for economic growth. 
This suggests that Saudi Arabia needs to remain open to international investment inflows, as well as bolstering and supporting its financial market development that could lead to the realization of sustainable development.

Generally, the positive effects of trade openness on economic growth or environmental quality are not automatic. Some policies based on improving investment in technologies and innovation, improving productivity, as well as improving and consolidating the quality of institutions and the ability to adapt and acquire new skills, should be accompanied to trade openness. Trade liberalization should, therefore, not be isolated to enhance sustainable development. Trade openness is fundamental for sustainable development. It helps to more efficiently allocate scarce resources and facilitates access to environmental technologies. However, most effective environmental regulations should be enforced to reduce trade-embodied emissions, and thus, reduce pollution in Saudi Arabia.

Despite all the empirical developments done in this study, some limits remain. Indeed, in the analysis of the impact of trade openness on Saudi Arabia's sustainable development, the study is only limited to both pillars of sustainable development (economic growth and $\mathrm{CO}_{2}$ emissions), but it does not consider the social component. Besides, a computable general equilibrium model would have been needed to fully determine the effects of trade openness on all the pillars of sustainable development simultaneously. This is why this study deserves to be extended-not only in the scientific approach, but also in the theme, because trade openness increasingly tends to be imposed on national economies.

Author Contributions: Conceptualization, M.B. and A.A.; methodology, M.B.; software, M.B.; validation, M.B., and A.A.; formal analysis, A.A.; investigation, A.A.; resources, A.A.; data curation, M.B.; writing-original draft preparation, A.A.; writing-review and editing, M.B.; visualization, A.A.; supervision, M.B.; project administration, M.B.; funding acquisition, A.A. All authors have read and agreed to the published version of the manuscript.

Funding: This research was funded by the deanship of scientific research—Najran University—Kingdom of Saudi Arabia under the grant number NU/SHED/16/119.

Acknowledgments: The authors would like to express their gratitude to the ministry of education and the deanship of scientific research-Najran University-Kingdom of Saudi Arabia for their financial and technical support under code number NU/SHED/16/119.

Conflicts of Interest: The authors declare no conflict of interest.

\section{References}

1. Balassa, B. Policy responses to exogenous shocks in developing countries. Am. Econ. Rev. 1986, 5, 75-78.

2. Weiss, E.B. Environment and trade as partners in sustainable development: A commentary. Am. J. Int. Law 1992, 86, 728-735. [CrossRef]

3. Chandia, K.E.; Gul, I.; Aziz, S.; Sarwar, B.; Zulfiqar, S. An analysis of the association among carbon dioxide emissions, energy consumption and economic performance: An econometric model. Carbon Manag. 2018, 9, 227-241. [CrossRef]

4. United Nations Conference on Trade and Development (UNCTAD). World Investment Report 2014: Investing in the SDGs: An Action Plan; United Nations: New York, NY, USA; Geneva, Switzerland, 2014.

5. Rodrik, D. Imperfect Competition, Scale Economies, and Trade Policy in Developing Countries. In Trade Policy Issues and Empirical Analysis; University of Chicago Press: Chicago, IL, USA, 1988; pp. 109-144.

6. Romer, P.M. Increasing returns and long-run growth. J. Political Econ. 1986, 94, 1002-1037. [CrossRef]

7. Lucas, R.E. The mechanics of economic development. J. Monet. Econ. 1988, 22, 3-42. [CrossRef]

8. Krueger, A.; Berg, A. Trade, Growth, and Poverty: A Selective Survey; IMF Working Paper WP/03/30; International Monetary Fund: Washington, DC, USA, 2003.

9. Antweiler, W.; Copeland, B.R.; Taylor, M.S. Is Free Trade Good for the Environment? Am. Econ. Rev. 2001, 91, 877-908. [CrossRef]

10. Aller, C.; Ductor, L.; Herrerias, M.J. The world trade network and the environment. Energy Econ. 2015, 52 Pt A, 55-68. [CrossRef]

11. Greenaway, D.; Morgan, W.; Wright, P. Trade liberalization and growth in developing countries. J. Dev. Econ. 2002, 67, 229-244. [CrossRef] 
12. Winters, L.A.; McCulloch, N.; McKay, A. Trade liberalization and poverty: The evidence so far. J. Econ. Lit. 2004, 42, 72-115. [CrossRef]

13. Grossman, G.M.; Helpman, E. Comparative advantage and long run growth. Am. Econ. Rev. 1990, 80, 796-815.

14. Rivera-Batiz, L.A.; Romer, P.M. International trade with endogenous technological change. Eur. Econ. Rev. 1991, 35, 971-1004. [CrossRef]

15. Taylor, M.S. Quality ladders and Ricardian trade. J. Int. Econ. 1993, 34, 225-243. [CrossRef]

16. Frankel, J.A.; Romer, D.H. Does Trade Cause Growth? Am. Econ. Rev. 1999, 89, 379-399. [CrossRef]

17. Ghirmay, T.; Grabowski, R.; Sharma, S. Exports, Investment, Efficiency, and Economic Growth in LDCs an empirical investigation. Appl. Econ. 2001, 33, 689-700. [CrossRef]

18. Mamun, K.A.; Nath, H.K. Export-Led Growth in Bangladesh: A Time Series Analysis. Appl. Econ. Lett. 2005, 12, 361-364. [CrossRef]

19. Felbermayr, G. Dynamic Panel Data Evidence on the Trade-Income Relation. Rev. World Econ. 2005, 141, 583-611. [CrossRef]

20. Reppas, P.A.; Christopoulos, D. The export-output growth nexus: Evidence from African and Asian countries. J. Policy Model. 2005, 27, 929-940. [CrossRef]

21. Hsiao, F.S.T.; Hsiao, M.C.W. FDI, Exports and GDP in East and Southeast Asia-Panel Data versus Time-Series Causality Analyses. J. Asian Econ. 2006, 17, 1082-1106. [CrossRef]

22. Narayan, P.K.; Narayan, S.; Prasad, B.C.; Prasad, A. Export-led growth hypothesis: Evidence from Papua New Guinea and Fiji. J. Econ. Stud. 2007, 34, 341-351. [CrossRef]

23. Rahman, M. Contributions of Exports, FDI and Expatriates' Remittances to Real GDP of Bangladesh, India, Pakistan and Sri Lanka. Southwest. Econ. Rev. 2007, 36, 141-154.

24. Jenkins, H.P.; Katircioglu, S.T. The bounds test approach for cointegration and causality between financial development, international trade and economic growth: The case of Cyprus. Appl. Econ. 2010, 43, 1699-1707. [CrossRef]

25. Gries, T.; Redlin, M. Trade Openness and Economic Growth: A Panel Causality Analysis; Working Papers CIE 52; Paderborn University, CIE Center for International Economics: Paderborn, Germany, 2012.

26. Muhammad, H.; Siddique, A.; Majeed, M.T. Energy Consumption, Economic Growth, Trade and Financial Development Nexus in South Asia; MPRA Paper No. 71245; University Library of Munich: Munich, Germany, 2015; pp. 658-682.

27. Fetahi-Vehapi, M.; Sadiku, L.; Petkovski, M. Empirical Analysis of the Effects of Trade Openness on Economic Growth: An Evidence for South East European Countries. Procedia Econ. Financ. 2015, 19, 17-26. [CrossRef]

28. Musila, J.W.; Yiheyis, Z. The impact of trade openness on growth: The case of Kenya. J. Policy Model. 2015, 37, 342-354. [CrossRef]

29. Gokmenoglu, K.K.; Amin, M.Y.; Taspinar, N. The relationship among international trade, financial development and economic growth: The case of Pakistan. Procedia Econ. Financ. 2015, 25, 489-496. [CrossRef]

30. Baharumshah, A.Z.; Rashid, S. Exports, Imports and Economic Growth in Malaysia: Empirical Evidence Based on Multivariate Time Series. Asian Econ. J. 1999, 13, 389-406. [CrossRef]

31. Shahbaz, M.; Khan, S.; Tahir, M.I. The dynamic links between energy consumption, economic growth, financial development and trade in China: Fresh evidence from multivariate framework analysis. Energy Econ. 2013, 40, 8-21. [CrossRef]

32. Alhowaish, A. Exports, Imports and Economic Growth in Saudi Arabia: An Application of Cointegration and Error-Correction Modeling. Pensée 2014, 76, 120-134.

33. Altaee, H.H.A.; Saied, S.M.; Esmaeel, E.S.; Adam, M.H.M. Financial Development, Trade Openness and Economic Growth: Evidence from Sultanate of Oman (1972-2012). J. Econ. Sustain. Dev. 2014, 5, 64-75.

34. Rehman, M.Z.; Ali, N.; Nasir, M.N. Linkage between Financial Development, Trade Openness and Economic Growth: Evidence from Saudi Arabia. J. Appl. Financ. Bank. 2015, 5, 127-141.

35. Kumar, R.R.; Stauvermann, P.J.; Loganathan, N.; Kumar, R.D. Exploring the role of energy, trade and financial development in explaining economic growth in South Africa: A revisit. Renew. Sustain. Energy Rev. 2015, 52, 1300-1311. [CrossRef]

36. Cetin, M. The Impact of Energy Consumption, Trade Openness and Financial Development on Economic Growth: Empirical Evidence from Turkey (1980-2014). Eur. J. Econ. Stud. 2016, 18, 459-469. 
37. Sunde, T. Foreign Direct Investment, Exports and Economic Growth: ARDL and Causality Analysis for South Africa. Res. Int. Bus. Financ. 2017, 41, 434-444. [CrossRef]

38. Ridzuan, A.R.; Ismail, N.A.; Che Hamat, A.F. Does Foreign Direct Investment Successfully Lead to Sustainable Development in Singapore? Economies 2017, 5, 29. [CrossRef]

39. Fayyaz, A. Muhammad Umar Draz Su-Chang Yang Causality nexus of exports, FDI and economic growth of the ASEAN5 economies: Evidence from panel data analysis. J. Int. Trade Econ. Dev. 2018, 27, 685-700.

40. Kong, Q.; Peng, D.; Ni, Y.; Jiang, X.; Wang, Z. Trade openness and economic growth quality of China: Empirical analysis using ARDL model. Forthcom. Financ. Res. Lett. 2020. [CrossRef]

41. Alalaya, M.M. ARDL Models Applied for Jordan Trade, FDI and GDP Series (1990-2008). Eur. J. Soc. Sci. 2008, 13, 605-616.

42. Marc, A. Is foreign direct investment a cure for economic growth in developing countries? Structural model estimation applied to the case of the south shore Mediterranean countries. J. Int. Bus. Econ. 2011, 11, 32-51.

43. Jouini, J. Linkage between international trade and economic growth in GCC countries: Empirical evidence from PMG estimation approach. J. Int. Trade Econ. Dev. 2014, 24, 341-372. [CrossRef]

44. Omri, A.; Daly, S.; Rault, C.; Chaibi, A. Financial development, environmental quality, trade and economic growth: What causes what in MENA countries? Energy Econ. 2015, 48, 242-252. [CrossRef]

45. Furuoka, F. Exports and economic growth in Sub-Saharan Africa: New insights from innovative econometric methods. J. Int. Trade Econ. Dev. 2017, 27, 830-855. [CrossRef]

46. Copeland, B.R.; Taylor, M.S. Trade, Growth, and the Environment. J. Econ. Lit. 2004, 42, 7-71. [CrossRef]

47. Frankel, J.A.; Rose, A.K. Is Trade Good or Bad for the Environment? Sorting Out the Causality. Rev. Econ. Stat. 2015, 87, 85-91. [CrossRef]

48. Dean, J.M.; Lovely, M.E. Trade growth, production fragmentation, and China's environment. In China's Growing Role in World Trade; University of Chicago Press: Chicago, IL, USA, 2010; pp. 429-469.

49. Le, T.H.; Le, H.C.; Taghizadeh-Hesary, F. Does financial inclusion impact $\mathrm{CO}_{2}$ emissions? Evidence from Asia. Forthcom. Financ. Res. Lett. 2020. [CrossRef]

50. Copeland, B.R.; Taylor, M.S. North-South Trade and the Environment. Q. J. Econ. 1994, 109, $755-787$. [CrossRef]

51. Cole, M.A. Trade, the pollution haven hypothesis and the environmental Kuznets curve: Examining the linkages. Ecol. Econ. 2004, 48, 71-81. [CrossRef]

52. Managi, S.; Hibiki, A.; Tsurumi, T. Does trade openness improve environmental quality? J. Environ. Econ. Manag. 2009, 58, 346-363. [CrossRef]

53. Le, T.H.; Chang, Y.; Park, D. Trade openness and environmental quality: International evidence. Energy Policy 2016, 92, 45-55. [CrossRef]

54. Halicioglu, F.; Ketenci, N. The impact of international trade on environmental quality: The case of transition countries. Energy 2016, 109, 1130-1138. [CrossRef]

55. Shahbaz, M.; Nasreen, S.; Ahmed, K.; Hammoudeh, S. Trade openness-carbon emissions nexus: The importance of turning points of trade openness for country panels. Energy Econ. 2017, 61, 221-232. [CrossRef]

56. Ertugrul, H.M.; Çetin, M.; Fahri, S.F.; Dogan, E. The impact of trade openness on global carbon dioxide emissions: Evidence from the top ten emitters among developing countries. Ecol. Indic. 2016, 67, 543-555. [CrossRef]

57. Shahzad, S.J.H.; Kumar, R.R.; Zakaria, M.; Hurr, M. Carbon emission, energy consumption, trade openness and financial development in Pakistan: A revisit. Renew. Sustain. Energy Rev. 2017, 70, 185-192. [CrossRef]

58. Lin, F. Trade openness and air pollution: City-level empirical evidence from China. China Econ. Rev. 2017, 45, 78-88. [CrossRef]

59. Sheikh, M.A.; Malik, M.A.; Masood, R.Z. Assessing the effects of trade openness on sustainable development: Evidence from India. Asian J. Sustain. Soc. Responsib. 2020, 5, 1-15. [CrossRef]

60. Ozturk, I.; Acaravci, A. The long-run and causal analysis of energy, growth, openness and financial development on carbon emissions in Turkey. Energy Econ. 2013, 36, 262-267. [CrossRef]

61. Dickey, D.A.; Fuller, W.A. Distribution of the Estimators for Autoregressive Time Series with a Unit Root. J. Am. Stat. Assoc. 1979, 74, 427-431.

62. Phillips, P.C.B.; Perron, P. Testing for a Unit root in Time Series Regression. Biometrika 1988, 75, 335-346. [CrossRef] 
63. Elliott, G.; Rothenberg, T.J.; Stock, J.H. Efficient tests for an autoregressive unit root. Econometrica 1996, 64, 813-836. [CrossRef]

64. Pesaran, M.H.; Shin, Y.; Smith, R.J. Bounds testing approaches to the analysis of level relationship. J. Appl. Econ. 2001, 16, 289-326. [CrossRef]

65. Alshehry, A.S.; Belloumi, M. Energy consumption, carbon dioxide emissions and economic growth: The case of Saudi Arabia. Renew. Sustain. Energy Rev. 2015, 41, 237-247. [CrossRef]

66. Hermes, N.; Robert, L. Foreign direct investment, financial development and economic growth. J. Dev. Stud. 2003, 40, 142-163. [CrossRef]

67. Durham, J.B. Absorptive capacity and the effects of foreign direct investment and equity foreign portfolio investment of economic growth. Eur. Econ. Rev. 2004, 48, 285-306. [CrossRef]

68. Alfaro, L.; Chanda, A.; Kalemli-Ozcan, S.; Sayek, S. FDI and economic growth: The role of local financial markets. J. Int. Econ. 2004, 64, 89-112. [CrossRef]

69. Kim, D.-H.; Lin, S.-C. Trade and growth at different stages of economic development. J. Dev. Stud. 2009, 45, 1211-1224. [CrossRef]

70. Trejos, S.; Barboza, G. Dynamic estimation of the relationship between trade openness and output growth in Asia. J. Asian Econ. 2015, 36, 110-125. [CrossRef]

71. Andersen, L.; Babula, R. The Link between Openness and Long-Run Economic Growth. J. Int. Commer. Econ. 2008, 2, 31 .

72. Wacziarg, R.; Welch, K.H. Trade Liberalization and Growth: New Evidence. World Bank Econ. Rev. 2008, 22, 187-231. [CrossRef]

73. Squalli, J.; Wilson, K. New Measure of Trade Openness. World Econ. 2011, 34, 1745-1770. [CrossRef]

74. Sakyi, D.; Villaverde, J.; Maza, A. Trade openness, income levels, and economic growth: The case of developing countries, 1970-2009. J. Int. Trade Econ. Dev. 2015, 24, 860-882. [CrossRef]

75. Ang, J. $\mathrm{CO}_{2}$ emissions, energy consumption, and output in France. Energy Policy 2007, 35, 4772-4778. [CrossRef]

76. Halicioglu, F. An econometric study of $\mathrm{CO}_{2}$ emissions, energy consumption, income and foreign trade in Turkey. Energy Policy 2009, 37, 1156-1164. [CrossRef]

77. Alshehry, A.S.; Belloumi, M. Investigating the causal relationship between fossil fuels consumption and economic growth at aggregate and disaggregate levels in Saudi Arabia. Int. J. Energy Econ. Policy 2014, 4, 531-545.

78. Belloumi, M.; Alshehry, A.S. Sustainable Energy Development in Saudi Arabia. Sustainability 2015, 7, 5153-5170. [CrossRef] 